\title{
MALARIA AT HUMAITA COUNTY, AMAZONAS STATE, BRAZIL. XVII - IMMUNE RESPONSE IN PATIENTS WITH PLASMODIUM FALCIPARUM ACCORDING TO GAMETOCYTES
}

\author{
Domingos Alves MEIRA (1), Paulo Roberto CURI (2), Jussara MARCONDES (3), Elinda Satie \\ MATSUOKA (4), Marina A. FAVRIN (4), Albert Boutros EL-KHOURY (5) and Norma Gerusa da \\ Silva MOTTA (6)
}

\section{S U M M A A $\mathbf{R}$}

In August 1983 the Authors studied 36 patients with Plasmodium falciparum malaria and 14 normal individuals born in Humaita region who had never had malaria, had no spleen enlargement and had negative parasitemia as well as passive hemagglutination. Medical histories were obtained and complete physical examination were performed in all of them just as blood tests, parasite density and lymphocyte typing. The lymphocytes were separated and then frozen in liquid nitrogen for later typing by rosette formation. The patients were divided in two groups according to the presence (13 patients) or abscence (23 patients) of gametocytes before treatment. Severe malaria was predominant in the group without gametocytes. The results showed a decrease in the T-cell numbers in Plasmodium falciparum acute malaria patients both with or without gametocytes before the treatment, while B-cell numbers were normal only in the patients with gametocytes. These observations as like as those previously reported by the Authors, permit to associate the presence of gametocytes in peripheral blood and normal number of B-cells in patients with mild Plasmodium falciparum malaria.

\section{N T R O D U C T I O N}

The association between the amount of circulating lymphocytes and the presence of ga-metocytes in Plasmodium falciparum malaria patients 11,12 has suggested the need to investigate the eventual relations among such events and the immune response of the patients.

In this way in previous study the Authors 11 had showed that: 1) there is an association among gametocytes, trophozoites, severity of clinical picture and amount of circulating lymphocytes in patients with Plasmodium falciparum malaria; 2) Plasmodium falciparum gametocytes probably come to the peripheral blood when the host's conditions become adverse to the asexual blood stage parasite survival; 3) when they appear in the peripheral blood during the disease, Plasmodium falcipa.

Research accomplished in the School of Medicine - Botucatu - UNESP, with support of National Council of Scientific and Technological Development - CNPq (Proc. 40.3705/82) and presented in "The Fourth Japan-Brazil Symposium on Science and Technology" in Botucatu, São Paulo, Brazil, 1984.

(1) Head professor of the Department of Infectious and Parasitologic Diseases, Dermatology and Radiology - School of Medicine - Botucatu - UNESP

(2) Doctor of the Department of Surgery School of Medicine - Botucatu - UNESP

(3) Instructor of the Department of Infectious and Parasitologic Diseases, Dermatology and Radiology - School of Medicine - Botucatu - UNESP

(4) Biologist of São Paulo State Public Functionary Hospital

(5) Fead of the Department of Blood Bank of São Paulo State Public Functionary Hospital

(6) Doctor of the Department of Microbiology and Immunology of Basic Institute of Medical and Agricultural Biology - UNESP 
MEIRA, D. A.; CURI, P. R.; MARCONDES, J.; MATSUOKA, E. S.; FAVRIN, M. A.; EL-KHOURY, A. B. \& MOTTA, N. G. da S. - Malaria at Humaita County, Amazonas State, Brazil. XVII - Immune response in patients with Plasmodium falciparum according to gametocytes. Rev. Inst. Med. trop. São Paulo 27:229-237, 1985.

rum gametocytes probably are an important index for the evaluation of prognosis and may be used to indicate the therapeutic schedule.

In posterior study the Authors 12 reported peripheral levels of leucocytes and lymphocytes in patients 'with Plasmodium falciparum malaria showing lower results in the patients without circulating gametocytes before the treatment and values next to normal in those with circulating gametocytes just as in prior investigations 11 .

CLYDE $^{5}$ and REILEY \& BARRETT-JR ${ }^{14}$ studied the behaviour of leucocytes in inhabitants of endemic regions and in patients with malaria and did not observe any relation between severity of illness and circulating leucocytes.

Otherwise, WILLIAMS et al. ${ }^{21}$ studying various severe acute human infections noted that poor prognosis was often associated with depression in total numbers of T-cells as well as of $T$ lymphocyte subpopulations as measured with $\mathrm{OKT}_{4}$ (helper-inducer).

WYLER \& OPPENHEIM 22 also suggested the importance of lymphocyte and its relation with immune response in malaria.

The studies of lymphocyte function in malaria patients with low blood stage asexual parasites 10 show that blastogenic responsiveness of peripheral blood mononuclear cells after stimulation with mitogens on cell surface antigen remains intact.

These findings seem to be in connection with the prior observations of the Authors 11,12 suggesting that as offen as the asexual parasitemia is low, sexual blood stage parasites are present in a high proportion and the clinical picture is mild. In the same way, TROYEBLOMBERG et al. ${ }^{20}$ reported no response in lymphocyte function in about $50 \%$ of all the acutely ill Plasmodium falciparum malaria patients. In some of these, the tests turned into positives two weeks later, when the asexual parasitemia was already absent.

DRUILHE et al. 8 concluded that mild human malaria infection does not modify the celldependent immune responses markedly, con trasting with suppression of delayed cutaneous reactions in severe Plasmodium falciparum malaria.
The purpose of this investigation was to demonstrate the behaviour of leucocytes, total lymphocytes and $\mathrm{T}$ and $\mathrm{B}$ cells in Plasmodium falciparum malaria patients before and after the treatment, according to gametocyte presence and its eventual association with immune response.

\section{MATERIAL AND METHODS}

In August 1983 the Authors studied $36 \mathrm{pa}$ tients with Plasmodium falciparum malaria and 14 normal individuals born in Humaita region who had never had malaria, with no spleen enlargement and negative both parasitemia and passive hemagglutination. Medical histories were obtained and complete physical examinations were performed in all of them as 'well as blood tests, parasite density 11 and lymphocyte typing. The lymphocytes were separated and then frozen in liquid nitrogen 9 for later typing by rosette formation 13 .

The patients 'were treated with clindamycin, $20 \mathrm{mg} / \mathrm{kg} /$ day alone or in association with chloroquine for 3 to 5 days. None of them received primaquine.

The degree of parasitemia was determined daily during the treatment 11 but blood tests and lymphocyte typing were performed only before the treatment and at the end of it.

The patients 'were divided in two groups according to the presence (13 patients) or absence ( 23 patients) of gametccytes before treatment. Severe malaria was predominant in the group without gametocytes.

The results were analysed by " $F$ " statistical method and paired and unpaired " $t$ " test 17 .

\section{RESULTS}

Table I shows that there was not significant difference between leucocyte and lymphocyte average in patients with gametocytes before the treatment and normal individuals. However, there was a significant difference between the leucocyte and lymphocyte averages in the patients without gametocytes and in those with gametocytes before the treatment as well as normal individuals. The leucocyte and the lymphocyte average were higher when the gametocytes were found in peripheral blood. 
MEIRA, D. A.; CURI, P. R.; MARCONDES, J.; MATSUOKA, E. S.; FAVRIN, M. A.; EL-KHOURY, A. B. \& MOTTA N. G. da S. - Malaria at Humaita County, Amazonas State, Brazil. XVII - Immune response in patients with Plasmo dium falciparum according to gametocytes. Rev. Inst. Med. trop. São Paulo 27:229-237, 1985.

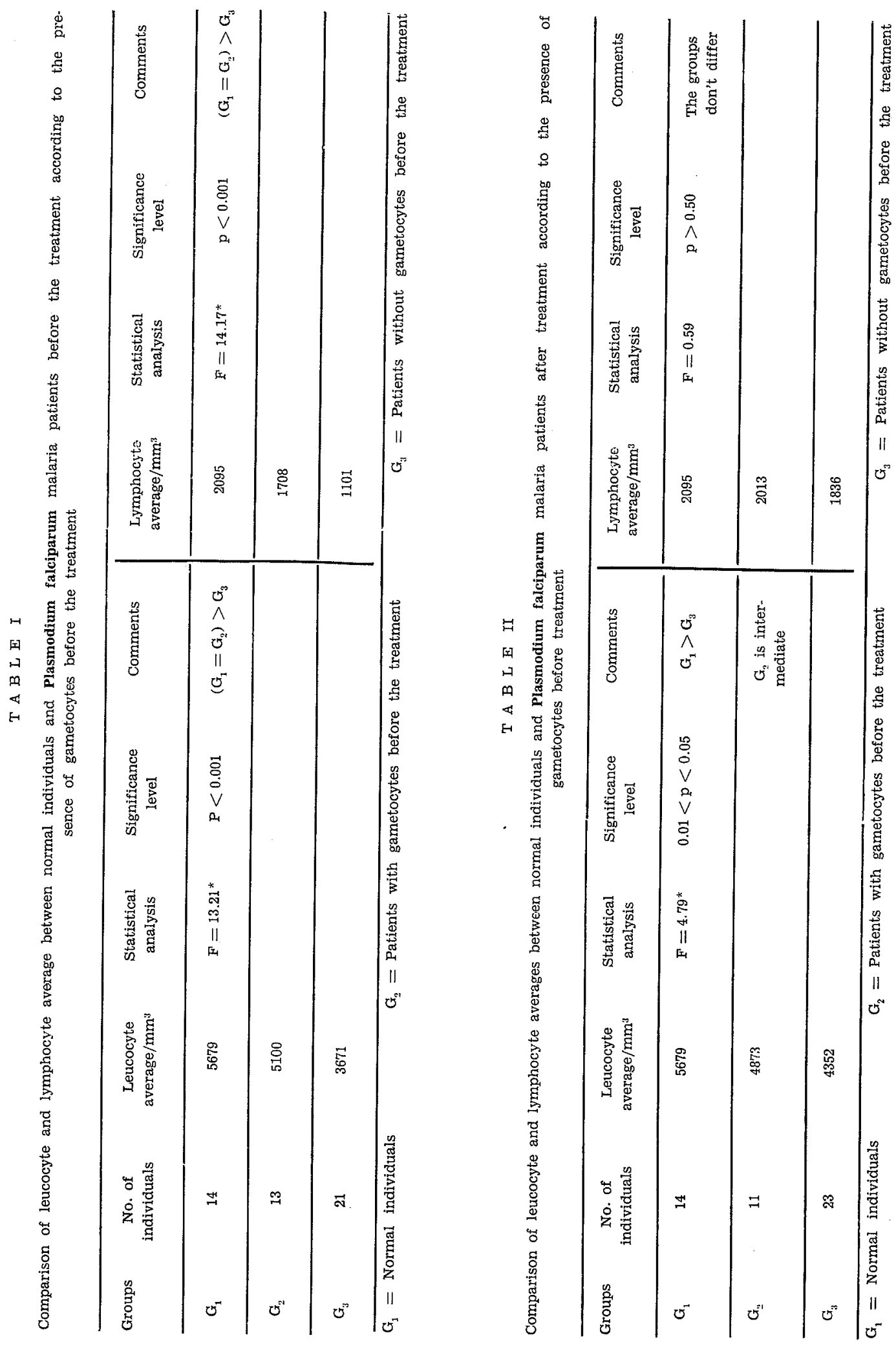


MEIRA, D. A.; CURI, P. R.; MARCONDES, J.; MATSUOKA, E. S.; FAVRIN, M. A.; EL-KHOURY, A. B. \& MOTTA, N. G. da S. - Malaria at Humaita County, Amazonas State, Brazil. XVII - Immune response in patients with Plasmo. dium falciparum according to gametocytes. Rev. Inst. Med. trop. São Paulo 27:229-237, 1985.

Table II shows that leucocyte average in Plasmodium falciparum malaria patients after the treatment, who had had no gametocytes before the treatment, was significantly different from leucocyte average in normal population.

Table III shows that there was significant difference between $T$ lymphocyte average in patients with or without gametocytes before treat. ment and normal individuals. It also denotes that, when B-cell average was considered, the difference between normal individuals and patients with gametocytes before the treatment was not significant. However, B lymphocyte amount in patients without gametocytes before the treatment had a tendency to low levels.

In Table IV it can be noted that $T$ and $B$ lymphocyte averages in Plasmodium falciparum malaria patients after the treatment did not differ from those found in normal individuals.

When lymphocyte and leucocyte averages obtained before and after treatment were compaired in patients with gametocytes before the treatment, the values did not differ significantly, as it is shown in Table $V$. However, patients who had no gametocytes before the treatment showed leucocyte and lymphocyte averages before and after the treatment differing significantly, since values obtained after the treatment were higher.
Table VI shows that B-cell average in patients who had gametocytes before the treatment was not significantly different before and after the treatment. In other hand, Plasmodium falciparum malaria patients with gametocytes before the treatment, $\mathrm{T}$ cell averages obtained before and after treatment differed significan. tly. This also was the pattern followed by $T$ and $\mathrm{B}$ cell averages in patients without gametocytes before the treatment. It is important to notice that in all these cases the amount of $T$ and $B$ lymphocytes was higher after the treatment.

Figure 1 shows the different behaviour of leucocytes, total lymphocytes and $\mathrm{T}$ and $\mathrm{B}$ lymphocytes in normal individuals and in patients before and after treatment, according to the presence of gametocytes before the treatment. The leucocytes, total lymphocytes and $T$ and $B$ cell amounts were very low before treatment, in patients who had no gametocytes. It also shows that $\mathbf{T}$ lymphocytes were very low before the treatment even in patients with gametocytes. However, B lymphocyte amount was higher before treatment in patients with gametocytes. Finally, after treatment there was a trend to normal amount of leucocytes, total lymphocytes and $\mathrm{T}$ and $\mathrm{B}$ cells in all patients.

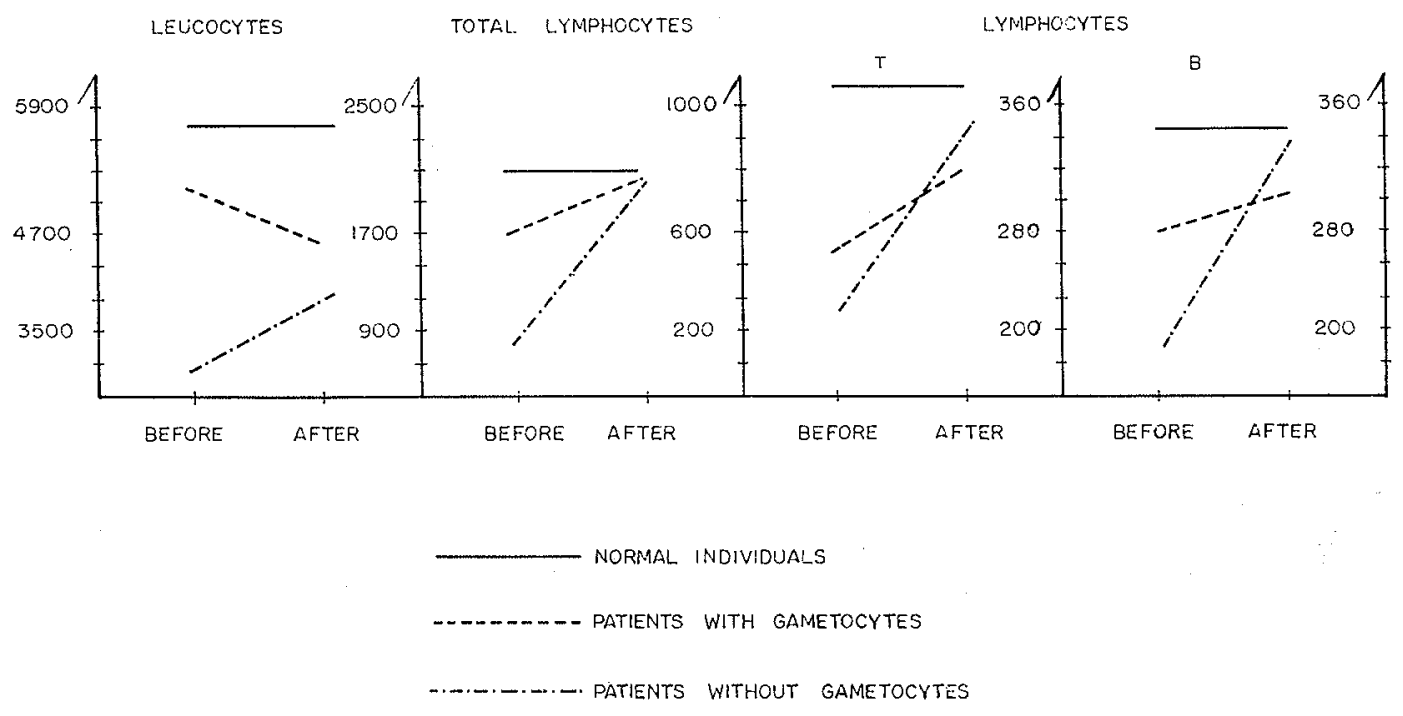

Fig. 1 - Leucocyte, total lymphocyte and $\mathbf{T}$ and $\mathbf{B}$ lymphocyte follow-up in normal individuals and in Plasmodium falciparum malaria patients, before and after treatment, according to the presence of gametocytes before the treatment. 
MEIRA, D. A.; CURI, P. R.; MARCONDES, J.; MATSUOKA, E. S.; FAVRIN, M. A.; EL-KHOURY, A. B. \& MOTTA, N. G. da S. - Malaria at Humaita County, Amazonas State, Brazil. XVII - Immune response in patients with Plasmodium falciparum according to gametocytes. Rev. Inst. Med. trop. São Paulo 27:229-237, 1985.

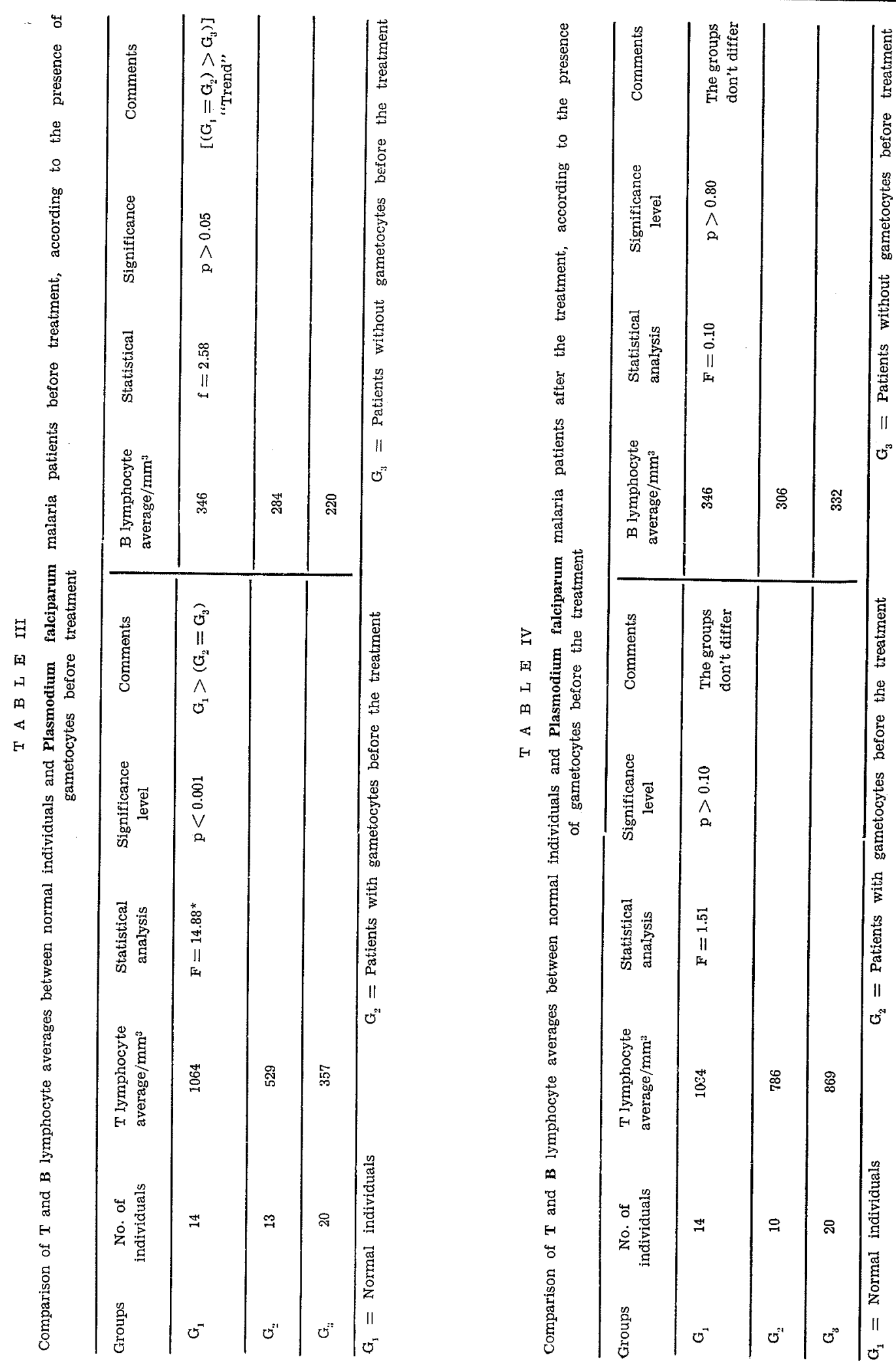


T A B L E V

Comparison of leucocyte and lymphocyte averages of Plasmodium falciparum malaria patients before and after treatment, according to the presence of gametocytes before the treatment

\begin{tabular}{|c|c|c|c|c|c|c|c|c|c|c|c|}
\hline \multirow[t]{2}{*}{ Groups } & \multirow[t]{2}{*}{$\begin{array}{l}\text { No. of } \\
\text { individuals }\end{array}$} & \multicolumn{2}{|c|}{$\begin{array}{c}\text { Leucocyte } \\
\text { average } / \mathrm{mm}^{3}\end{array}$} & \multirow[t]{2}{*}{$\begin{array}{l}\text { Statistical } \\
\text { analysis }\end{array}$} & \multirow[t]{2}{*}{$\begin{array}{l}\text { Significance } \\
\text { level }\end{array}$} & \multirow[t]{2}{*}{ Comments } & \multicolumn{2}{|c|}{$\begin{array}{l}\text { Lymphocyte } \\
\text { average } / \mathrm{mm}^{3}\end{array}$} & \multirow[t]{2}{*}{$\begin{array}{l}\text { Statistical } \\
\text { analysis }\end{array}$} & \multirow[t]{2}{*}{$\begin{array}{l}\text { Significance } \\
\text { level }\end{array}$} & \multirow[t]{2}{*}{ Comments } \\
\hline & & Before & after & & & & Before & after & & & \\
\hline$G_{2}$ & 11 & 5136 & 4873 & $t=0.44$ & $\mathrm{p}>0.50$ & Before $=$ After & 1724 & 2013 & $t=1.03$ & $\mathrm{p}>0.30$ & Before $=$ After \\
\hline $\mathrm{G}_{3}$ & 23 & 3578 & 4365 & $\mathrm{t}=1.75$ & $0.05<p<0.10$ & Before $\leq$ After & 1015 & 1836 & $t=6.30^{*}$ & $p<0.001$ & Before < After \\
\hline
\end{tabular}

$\mathrm{G}_{2}=$ Patients with gametocytes before the treatment

$G_{3}=$ Patients without gametocytes before the treatment

T A B L E VI

Comparison of $\mathrm{T}$ and $\mathrm{B}$ lymphocyte averages of Plasmodium falciparum malaria patients before and after the treatment, according to the presence of gametocytes before the treatment

\begin{tabular}{|c|c|c|c|c|c|c|c|c|c|c|c|}
\hline \multirow{3}{*}{$\begin{array}{l}\text { Groups } \\
\mathrm{G}_{22}\end{array}$} & \multirow{3}{*}{$\begin{array}{c}\begin{array}{c}\text { No. of } \\
\text { irdividuals }\end{array} \\
10\end{array}$} & \multicolumn{2}{|c|}{$\begin{array}{l}\text { T lymphocyte } \\
\text { average } / \mathrm{mm}^{3}\end{array}$} & \multirow[t]{2}{*}{$\begin{array}{c}\text { Statistical } \\
\text { analysis }\end{array}$} & \multirow[t]{2}{*}{$\begin{array}{l}\text { Significance } \\
\text { level }\end{array}$} & \multirow[t]{2}{*}{ Comments } & \multicolumn{2}{|c|}{$\begin{array}{l}\text { B lymphocyte } \\
\text { average } / \mathrm{mm}^{3}\end{array}$} & \multirow[t]{2}{*}{$\begin{array}{c}\text { Statistical } \\
\text { analysis }\end{array}$} & \multirow[t]{2}{*}{$\begin{array}{l}\text { Significance } \\
\quad \text { level }\end{array}$} & \multirow[t]{2}{*}{ Comments } \\
\hline & & Before & after & & & & Befo & after & & & \\
\hline & & 490 & 786 & $t=2.41^{*}$ & $0.02<\mathrm{p}<0.05$ & Before $<$ After & 299 & 306 & $t=0.52$ & $p>0.50$ & Before $=$ After \\
\hline$G_{3}$ & 17 & 357 & 812 & $t=5.34^{*}$ & $\mathrm{p}<0.01$ & Before $<$ After & 203 & 325 & $t=2.27^{*}$ & $0.02<\mathrm{p}<0.05$ & Before $<$ After \\
\hline
\end{tabular}


MEIRA, D. A.; CURI, P. R.; MARCONDES, J.; MATSUOKA, E. S.; FAVRIN, M. A.; EL-KHOURY, A. B. \& MOTTA, N. G. da S. - Malaria at Humaita County, Amazonas State, Brazil. XVII — Immune response in patients with Plasmodium falciparum according to gametocytes. Rev. Inst. Med. trop. São Paulo 27:229-237, 1985.

\section{DISGUSSION}

The results show that the amount of leucocyte and total lymphocyte was similar in normal individuals and in the patients with gametocytes before and after treatment. Leucopenia and lymphopenia were observed in the patients without gametocytes before treatment, with tendency to normal values after it. The amounts of $T$ lymphocyte were very low in both the patient groups before treatment, with tendency to increase in the convalescence period. The B lymphocyte behaviour was different in the two patient groups: patients with gametocytes had normal amounts and those without gametocytes had very low amounts.

The results show a decrease in T-cell numbers in Plasmodium falciparum acute malaria patients both with or without gametocytes before the treatment, while B-cell numbers, are normal only in the patients with gametocytes before the treatment. These observations as well as those previously reported 11,12 permit to associate the presence of gametocytes in peripheral blood with normal number of $\mathrm{B}$ cells in patients with mild Plasmodium falciparum malaria.

The studies in malaria so far reported in immunity field are based on the evaluation of total lymphocyte numbers, lymphocyte subsets as well as lymphocyte function with no connection 'with gametocytes in blood stream.

In this way RITCHIE et al. ${ }^{15}$ and BERTOUCH et al. ${ }^{3}$ reported in their studies the already known diurnal rhythm of total lymphocyte numbers and the similar rhythm of several lymphocyte subsets. They showed the lowest levels of all subsets at 9:00 hours and the highest levels at 21:00 hours. In the present serie, lymphocyte levels obtained from the patients were always compared with those from healthy subjects and blood for white cell counts was collected from 9:00 hours to 15:00 hours.

WYLER ${ }^{23}$ has observed a decrease in total lymphocyte count and in both percentage as well as concentration of $\mathrm{T}$ cell as compared to levels following treatment. The Authors believes that this decrease in peripheral $\mathrm{T}$ cells may represent sequestration of this population to spleen or other specific lymphoid organ. The production of antibody in malaria and its probable protective role in falciparum infections indicate that B-cell activity is important as considered by COHEN et al. 6 .

TROYE-BLOMBERG et al. ${ }^{19}$ and MAC DERMOTT et al. 10 have reported besides the decrease in the absolute and relative frequencies of $\mathrm{T}$ cells in the blood of Plasmodium falcipa. rum patients, alterations of lymphocyte function mainly in the severe infections. TROYE-BLOMBERG et al. ${ }^{19}$ have shown that the ratio between $\mathrm{T}_{4}+\mathrm{T}$ cell (including the helper/inducer subsets) and $T_{8}+T$ cell (including the supressor and cytotoxic subsets) were below 1:1 while they were close to $2: 1$ in the controls. These results indicate that the relative frequency of $T_{8}+T$ cell, expressed as percentage of total $T$ cells $\left(\mathrm{T}_{3}+\right)$ was significantly elevated in Plas. modium falciparum patients, as concluded by the Authors.

During the investigation of cell-mediated immunity in malaria patients BALLET et al. ${ }^{2}$ and DRUILHE et al. 7 observed that lymphocyte proliferative responses were not altered in children and in adults with a moderate parasitaemia of Plasmodium falciparum while these responses were totally depressed in two cases of cerebral malaria. In subsequent studies DRUILHE ei al. ${ }^{8}$, investigated 63 Plasmodium falciparum infected patients and of these 21 had cerebral malaria and 12 had very high parasitaemia. They observed that in the most cases depression of responses was related to a high parasitaemia and concluded that mild human malaria infection does not modify the celldependent immune responses markedly. They also suggest that Plasmodium falciparum malalaria is able to suppress delayed cutaneous reations, particularly to soluble antigens, and "in vitro" responses to antigens. It is important to express that these Authors 2,7,8 associated their observations to asexual parasitaemia only.

The association of both our previous 11,12 and present results, with those reported by the above mentioned Authors 2,7,8 permit to suggest that Plasmodium falciparum infected patients with gametocytes in the peripheral blood before the treatment do not show lymphocyte function markedly modified. 
MEIRA, D. A.; CURI, P. R.; MARCONDES, J.; MATSUOKA, E. S.; FAVRIN, M. A.; EL-KHOURY, A. B. \& MOTTA, N. G. da S. - Malaria at Humaita County, Amazonas State, Brazil. XVII - Immune response in patients with Plasmodium falciparum according to gametocytes. Rev. Inst. Med. trop. São Paulo 27:229-237, 1985.

Another aspect that must be considered is refered to the loss of immunity after malaria chemotherapy 1 . In this way, SALMERON \& LIPSKY 16 and BHATTACHARYA et al. 4 have reported the immunossupressant activity of chloroquine in recent investigations, and THONG et al. ${ }^{18}$ showed the same effect with primaquine.

Thus, in area of transmission it should be considered the contra-indication of early use of primaquine as gametocydal agent in the treatment of Plasmodium falciparum malaria patients, although additional studies on gametocytes and their association with the immune response should still be done.

\section{RESUMO}

Malária no Município de Humaitá, Estado do Amazonas. XVII - Resposta imune em doentes com infecção pelo Plasmodium falciparum em relação aos gametócitos

Em agosto de 1983, os Autores, estudaram 36 doentes com infecção causada pelo Plasmodium falciparum e 14 indivíduos normais, nascidos na região de Humaitá, que nunca tiveram malária, sem esplenomegalia, com exame parasitológico de sangue e hemaglutinação passiva negativas. Todos eles foram submetidos à observação clínica completa, exame hematológico, exame parasitológico de sangue e tipagem de linfócitos. Os linfócitos foram isolados e congelados em nitrogênio líquido, para posterior tipagem pela formação de rosetas. Os doentes foram classificados em dois grupos de acordo com a presença (13 doentes), ou ausência (23 doentes) de gametócitos antes do tratamento. Houve predomínio de formas graves no grupo de doentes sem gametócitos. Os resultados mostraram diminuição do número de linfócitos $T$ em ambos os grupos de doentes, com ou sem gametócitos antes do tratamento, enquanto que o número de linfócitos $\mathrm{B}$ foi normal apenas no grupo de doentes com gametócitos. Essas observações, assim como as que foram relatadas pelos Autores anteriormente, permitem associar a presença de gametócitos circulantes com o número normal de células $\mathrm{B}$ em doentes com formas leves de malária causada pelo Plasmodium falciparum.

\section{ACKNOWLEDGEMENTS}

We wish to thank the aid of Fundação Projeto Rondon, Directory of Advanced Campus and Humaitá - SUCAM.

\section{REFERENCES}

1. ALLISON, A. C. \& EUGUT, E. M. - The role of cell mediated immune responses in resistance to malaria, with special reference to oxidant stress. Ann. Rev. Immunol. 1: 331-392, 1983.

2. BALLET, J. J.; AGRAPART, M. MONJOUR, L.; BOUR. DILLON, F.; KARAM, M.; KYELEM, J. M. \& STOECKEL, P. - Etude de l'immunité humorale et cellulaire après vaccination anti tétanique chez l'enfent african malnutri et paludéen. II - Etude in vitro des réponses cellulaires non spécifiques et spécifiques de l'anatoxine tétanique. Bull. Wld. Hith. Org. 50: 597. 604, 1982.

3. BERTOUCH, J.; ROBERTS-THOMSON, R. J. \& BRADLEY, J, - Diurnal variation of Iymphocyte subsets identified by monoclonal antibodies. Br. Med. J. 286: 1171-1172, 1983 .

4. BHATTACHARYA, S. K.; PILLAT, C. R.; MATHUR, M. \& SEN, P. - Effect of chloroquine and some other antimalarials on the immune mechanism in experimental animals. J. Pharm. Pharmacol. 36: 268-269, 1984.

5. CLYDE, D. F. - A study of mononuclear leucocyte and neutrophil patterns among east africans partially immune to malaria. J. Trop. Med. Hyg. 67: 25-30, 1964.

6. COHEN, S.; Mc GREGOR, I. A. \& CARRINGTON, S. - Gammaglobulin and acquired immunity to malaria. Nature 192: $733-736,1961$.

7. DRUILHE, P.; BALLET, J. J.; QUERLEUX, M. A.; AGRAPART, M. \& GENTILINI, M. - Modulation by Plasmodium falciparum of the proliferation of human lymphocytes. Cancer Immunology and Parasite Immunology. INSERM 97: 407-423, 1980.

8. DRUILHE, P.; BRASSEUR, P.; AGRAPART, M.; BAL IET, J. J.; CHANTHAVANICH, P.; IOOAREESUWAN, S.; WHITE, N.; WARRELL, M.; WARRELL, D.; THARAVANIJ, S. \& GENTILINI, M. - T cell responsiveness in severe Plasmodium falciparum malaria. Trans. Roy. Soc. Trop. Med. Hyg. 77: 671-672, 1983.

9. HORS, J.; PREUD'HOMME, J. L.; TOULZA-ZAPATERIA, M. T.; GUILLETBIGOT, J.; ROY, J. P. \& DAUSSET, J. - A simplified method for freezing lymphocytes in nitrogen vapors. Transplant. 15: 417-419, 1973.

10. MAC DERMOTT, R. P.; WELLS, R. A.; ZOLYOMI, S.; PAVANAND, K.; PHISPHUMVIDHI, P.; PERMPANICH, B. \& GILBREATH, M. - Examination of peripheral blood mononuclear cells and sera from Thai adults naturally infected with malaria in assays of blastoge- 
MEIRA, D. A.; CURI, P. R.; MARCONDES, J.; MATSUOKA, E. S.; FAVRIN, M. A.; EL-KHOURY, A. B. \& MOTTA, N. G. da S. - Malaria at Humaita County, Amazonas State, Brazil. XVII - Immune response in patients with Plasmo dium falciparum according to gametocytes. Rev. Inst. Med. trop. São Paulo 27:229-237, 1985.

nic responsiveness to mitogenic lectins and allogenic cell surface antigens. Infect. Immun. 30: 781-785, 1980.

11. MEIRA, D. A.; MARCONDES, J.; BARRAVIERA, B.; PEREIRA, P. C. M. ; RUI, P. \& CURI, P. R. - Malaria at Humaita County, Amazonas State, Brazil. XVI - Gametocytes and lymphocytes studied in patients with Plasmodium falciparum. Rev. Inst. Med. trop. São Paulo 24 (Supl. 6): 32-39, 1982.

12. MEIRA, D. A.; MARCONDES, J.; CURI, P. R.; GUIMARÃES, F. R. \& DI SANTI, S. M. - Malária no Município de Humaitá, Estado do Amazonas. XXXIII - Comportamento dos gametócitos e linfócitos em doentes com Plasmodium falciparum. Apresentado no XX Congresso da Sociedade Brasileira de Medicina Tropical e I Congresso da Sociedade Latino-Americana de Medicina Tropical. Salvador, Bahia, fevereiro de 1984.

13. MENDES, N. F.; TOLNAI, M. E. A.; SILVEIRA, N. P. A.; GILBERTSEN, R. B. \& METZGAR, R. S. Technical aspects of rosette tests used to detect human complement receptor (B) and sheep crythrocyte binding (T) Iymphocytes. J. Immunol. 111: 860-867, 1973 .

14. REILEY, C. G. \& BARRETT-JR., O. N. - Leukocyte response in acute malaria. Am. J. Med. Sc. 262: 153$158,1971$.

15. RITCHIE, A. W. S.; OSWALD, I.; MICKEM, H. S.; BOYD, J. E.; ELTON, R, A.; JAZWINSKA, E. \& JAMES, K. - Circadian variation of lymphocyte subpopulations: a study with monoclonal antibodies. $\mathbf{B r}$. Med. J. 286: $1773-1775,1983$.

16. SALMERON, G. \& LIPSKY, P. E. - Immunosupressive potential antimalarials, Am. J. Med. 18: 19-24, 1983.
17. SNEDCOR, G. W. \& COCHRAN, W. G. - Statistical Methods. 7a. ed., Ames, Iowa, The Iowa State University, 1980, $505 \mathrm{p}$.

18. THONG, Y. H.; FERRANTE, A. \& ROWAN-KELLY B. - Primaquine inhibits mitogen-induced human lymphocyte proliferative responses. Trans. Roy. Soc. Trop Med. Hyg. 72: 537-539, 1978.

19. TROYE-BLOMBERG, M.; SJÖHOLM, P. E.; PERLMANN, H.; PATARROYO, M. E. \& PERLMANN, P. Regulation of the immune response in Plasmodium falciparum malaria. I - Non specific proliferative responses "in vitro" and characterization of lymphocytes. Clin. Exp. Immunol. 53: 335-344, 1983.

20. TROYE-BLOMBERG, M.; PERLMANN, H.; PATARROYO, M. E. \& PERLMANN, P. - Regulation of the immune response in Plasmodium falciparum malaria. II - Antigen specific proliferative responses "in vitro". Clin. Exp. Immunol. 53: 345-353, 1983.

21. WILLIAMS, R. C.; KOSTER, F. T. \& KILPATRICK, K. A. - Alterations in lymphocyte cell surface markers during various human infections. Am. J. Med. 75: 807-816, 1983.

22. WYLER, D. J. \& OPPENHEIM, J. J. - Lymphocyte transformation in human Plasmodium faleiparum malaria. J. Immunol. 113: 449-454, 1974.

23. WYLER, D. J. - Peripheral Iymphocyte subpopulations in human falciparum malaria. Clin. Exp. Immunol. 23: $471-476,1976$

Recebido para publicação em 12/11/1984. 